\title{
Analisis Faktor-Faktor yang Mempengaruhi Pendapatan Usaha Ternak Ayam Petelur di Kabupaten Lima Puluh Kota
}

\author{
Helmi Ali ${ }^{*} * 1$, Rihan Ifebri ${ }^{2}$, Ratna Agustia ${ }^{2}$, Mega Putri ${ }^{2}$, Zulkarnaini ${ }^{3}$ \\ ${ }^{1}$ Sekolah Tinggi Ilmu Ekonomi (STIE) Haji Agus Salim Bukittinggi \\ ${ }^{2}$ Pascasarjana Magister Ilmu Ekonomi Pertanian, Universitas Andalas \\ ${ }^{3}$ Fakultas Pertanian, Universitas Taman Siswa Padang \\ *helmi_akbary@yahoo.com
}

\begin{abstract}
Abstrak. Sentra produksi usaha ternak ayam petelur di Sumatera Barat adalah kota Payakumbuh dan kabupaten Lima Puluh Kota. Keberlanjutan usaha ternak ayam petelur perlu diketahui faktor produksi apa yang menyebabkan peternak mampu bertahan. Penelitian ini menganalisis satu periode produksi kegiatan usaha ternak ayam petelur dan faktorfaktor produksi apa yang mempengaruhi pendapatan usaha ternak ayam ras petelur serta posisi produksi dalam siklus produksi. Metode penelitian dilakukan dengan metode survey, yang dilakukan kepada 30 peternak ayam ras petelur yang berlokasi di kecamatan Guguak dan Mungka. Pengambilan sampel dilakukan dengan metode simple random sampling. Analisis data mengungkap beberapa variabel faktor-faktor produksi sebagai penentu pendapatan peternak ayam petelur. Hasil penelitian menunjukkan bahwa pendapatan rata-rata perbulannya adalah Rp 44.845.880.00. Hasil pendugaan model variabel bebas secara simultan positif dan signifikan mempengaruhi pendapatan. Pendugaan variabel produksi dalam model ternyata $74 \%$ bisa menjelaskan variabel pendapatan. Secara empirik model pendugaan memperlihatkan posisi produksi usahaternak ayam petelur adalah increasing return to scale.
\end{abstract}

Kata Kunci: faktor produksi, pendapatan, usaha ternak ayam ras petelur

\section{PENDAHULUAN}

Usaha ternak merupakan sumber pangan utama yang harus menjadi pusat perhatian dan harus dicukupi untuk suatu wilayah ekonomi. Bila tidak akan mengganggu kegiatan ekonomi, karena harus impor. Kegiatan ekonomi sektor peternakan ini berada di tingkat rakyat, sehingga dikenal ekonomi kerakyatan. Dinas perternakan (2015), menyebutnya sektor peternakan merupakan sektor penting dalam perkembangan ekonomi kerakyatan karena pada sektor ini tumbuh usaha-usaha yang bisa menunjang kehidupan rakyat, karena itu pengembangan peternakan dapat memberikan harapan untuk masa yang akan datang seiring dengan meningkatnya jumlah penduduk, peningkatan pendapatan dan peningkatan kesadaran masyarakat untuk mengkonsumsi pangan yang bergizi Pembangunan subsektor peternakan bidang perunggasan, khususnya peternakan ayam ras petelur menjadi salah satu usaha yang diharapkan dapat membawa perubahan perekonomian masyarakat ke arah yang lebih baik. Sentra produksi peternakan ayam ras petelur di sumatera barat dapat mencukupi konsumsi masyarakat sumatera barat usaha peternakan ayam ras petelur berusaha menunjukkan kemampuannya untuk menjadi usaha peternakan yang diandalkan.

Data menunjukkan tahun 2015 subsektor peternakan memberikan kontribusi sebesar 4,47\% terhadap pendapatan daerah di kabupaten Lima Puluh Kota (BPS Lima Puluh Kota, 2015). Hal ini menunjukan bahwa subsektor peternakan merupakan salah satu sumber pemasukan yang patut di perhitungkan dalam sektor pertanian.

Sektor peternakan cukup berperan di kabupaten Lima Puluh Kota di banding sektor lain, karena kontribusi sektor pertanian terhadap PDRB tahun 2015 yang menunjukkan angka sebesar 34,61\% untuk pendapatan sektor pertanian di Kabupaten Lima Puluh Kota disini termasuk dari sektor peternakan. Kecamatan yang ada di Kabupaten Lima Puluh Kota, menunjukkan bahwa kecamatan Guguak dan Mungka merupakan daerah penyumbang pemasukan pemerintah pada subsektor peternakan untuk usaha ayam ras

To cite this article: Ali, H., R. Ifebri, R. Agustia, M. Putri N, dan Zulkarnain. 2019. Analisis Faktor-Faktor yang Mempengaruhi Pendapatan Usaha Ternak Ayam Petelur di Kabupaten Lima Puluh Kota. Unri Conference Series: Agriculture and Food Security 1: 120-126. https://doi.org/10.31258/unricsagr.1a16 
petelur, dan perkembangan peternakan ayam petelur di kedua Kecamatan ini sangat pesat (BPS Lima Puluh Kota, 2015).

Berkembangnya usaha ayam petelur di Kecamatan Guguak dan Kecamatan Mungka tidak terlepas dari produktivitas aspek usaha dan pengelolaannya, diharapkan pendapatan pengusaha ayam petelur terus naik seiring dengan produksinya, tetapi perlu diperhatikan bahwa ada komponen biaya yang harus dikeluarkan pengusaha ayam petelur untuk menghasilkan produksinya. Penjelasan fenomena dan realitas di atas memperkuat perlu dilakukan penelitan, dengan mengajukan pertanyaan penelitian, yakni: faktor-faktor produksi apa yang berkontribusi besar terhadap pendapatan usaha ternak ayam petelur; dan bagaimana posisi produksi usaha ternak ayam petelur dalam proses siklus produksi.

Dengan penelitian ini bertujuan untuk faktor-faktor produksi yang berperan besar terhadap pendapatan usaha ternak ayam ras petelur, sehingga usahanya berlanjut. Selanjutnya, untuk mengetahui posisi produksi yang akan dapat memprediksi kemampuan usaha ternak ini mampu bertahan dan berlanjut (survive and sustainability).

\section{METODE}

Penelitian ini dirancang dengan memilih dua kecamatan, yakni Guguk dan Mungka di kabupaten Lima Puluh Kota sebagai sentral produksi ayam ras petelur di Sumatera Barat. Populasi penelitian ini adalah para peternak ayam ras petelur yang ada di kedua kecamatan tersebut sejumlah 306 uasaha ternak rakyat. Pengambilan sampel dilakukan dengan metode acak sederhana (simple random sampling) dengan jumlah responden penelitian 10 persen dari populasi penelitian, ditetapkan sebanyak 30 orang peternak.

Data dikumpulkan dengan menggunakan metode survey. Menurut Singarimbun dan Effendi, 1995; Wati.R, Amna.S; Karmila.D, 2008, yang menyebutkan metode survei adalah metode pengumpulan informasi dari sebagian sampel untuk mewakili seluruh populasi. Pemilihan metode ini dinilai lebih tepat karena mampu mengumpulkan informasi yang lebih dalam dari responden. Responden akan diberikan pertanyaan dalam bentuk daftar pertanyaan (kuesioner) dan dipandu oleh tenaga pencacah (surveyor).

Dalam penelitian ini data yang digunakan berupa data primer dan data sekunder. Data primer diperoleh dari hasil wawancara langsung dengan peternak ayam ras petelur yang ada di lokasi penelitian. Sementara itu data sekunder diperoleh dari literatur, BPS, Dinas Peternakan dan instansi terkait lainnya. Pada penelitian ini menggunakan analisis penelitian yaitu: 1) Analisis deskriptif kuantitatif untuk menjelaskan bagaimana menghitung biaya produksi, penerimaan dari produksi serta pendapatan yang diperoleh pada usaha peternakan ayam ras petelur dan 2). Analisis deskriptif kuantitatif dengan menggunakan analisis regresi linier berganda yang di transformasikan ke dalam bentuk persamaan regresi Cocos nucifera. Analisis ini digunakan untuk melihat pengaruh faktor produksi terhadap pendapatan peternak ayam petelur di kecamatan Guguak dan Mungka,

\section{Spesifikasi Model Analisis}

Model analisis faktor-faktor produksi yang digunakan untuk melihat biaya produksi, penerimaan dan pendapatan peternak ayam petelur dengan rumus pada tabel berikut.

Tabel 1. Rumus umum analisis biaya produksi usaha ternak ayam petelur

\begin{tabular}{lll}
\hline TC $=$ FC + VC & $\mathrm{R}=$ Q.P & $\pi=\mathrm{TR}-\mathrm{TC}$ \\
Keterangan: & Keterangan: & Keterangan: \\
TC = Total biaya & $\mathrm{R}=$ Penerimaan & $\pi=$ Pendapatan \\
FC = Biaya tcetap & $\mathrm{Q}=$ Jumlah produksi & TR = Total Penerimaan \\
VC = Biaya variabel & $\mathrm{P}=$ Harga produk & $\mathrm{TC}=$ Total biaya \\
\hline
\end{tabular}

Untuk melihat pengaruh faktor-faktor produksi terhadap pendapatan usahaternak ayam petelur di kabupaten Lima Puluh Kotadigunakan persamaan linear regresi berganda berikut.

$$
\mathrm{Y}=\alpha \mathrm{o}+\beta 1 \mathrm{X} 1+\beta 2 \mathrm{X} 2+\beta 3 \mathrm{X} 3+\beta 4 \mathrm{X} 4+\beta 5 \mathrm{X} 5+\beta 6 \mathrm{X} 6+\varepsilon i
$$

$\begin{array}{ll}\text { dimana: } & \\ \mathrm{Y} & =\text { pendapatan usahaternak ayam ras petelur (rupiah) } \\ \alpha \mathrm{o} & =\text { konstanta } \\ \beta 1, \beta 2, \beta 3, \beta 4, \beta 5, \beta 6 & \text { = koefisien regresi } \\ \mathrm{X} 1 & =\text { biaya kandang (rupiah) } \\ \mathrm{X} 2 & =\text { tenaga kerja (rupiah) }\end{array}$




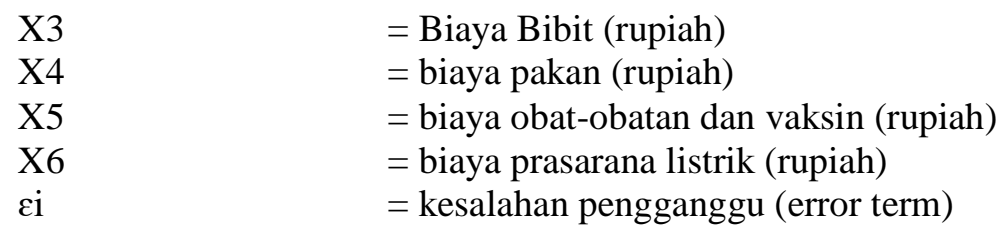

Dalam persamaan diatas variabel X1 sampai dengan X6 merupakan variabel bebas ekonomi yang bisa dihitung dengan satuan mata uang rupiah, sementara itu variabel $\mathrm{Y}$ merupakan variabel terikat secara ekonomi yang bisa dihitung dengan satuan mata uang rupiah.

Untuk memudahkan persamaan di atas, maka persamaan tersebut diubah menjadi bentuk linear berganda dengan melogaritmakan persamaan tersebut. Pendugaan parameter dapat dilakukan dengan menggunakan analisis dan metode kuadrat terkecil (ordinary least square/OLS) yang diperoleh dari model fungsi asal menjadi sebagai berikut:

$$
\mathrm{LnY}=\operatorname{Ln} \alpha \mathrm{O}+\beta 1 \operatorname{LnX} 1+\beta 2 \operatorname{LnX} 2+\beta 3 \operatorname{LnX}+\beta 4 \operatorname{LnX} 4+\beta 5 \operatorname{LnX} 5+\beta 6 \operatorname{LnX} 6+\varepsilon i
$$

Persamaan inifungsi sama dengan yang telah dijabarkan pada model persamaan sebelumnya dan diselesaikan dengan cara regresi linear berganda, pada persamaan tersebut terlihat bahwa nilai semua $\beta$ adalah tetap walaupun nilai variable $X$ telah di logaritmakan. Penormalan model dengan nilai $\beta$ pada fungsi Coub-Douglas sekaligus menunjukkan elastisitas $\mathrm{X}$ terhadap $\mathrm{Y}$ sehingga ada tiga fase kemungkinan akan terjadi dalam siklus produksi, yakni: $\beta<1$ disebut decreasing return to scale; $\beta>1$ disebut increasing return to scale; dan $\beta=1$ disebut constan return to scale.

\section{Pengujian Asumsi Klasik}

Pengujian ini dimaksudkan untuk mendeteksi ada tidaknya autokorelasi, multikolinearitas, dan heterokedastisitas. Apabila terjadi penyimpangan terhadap asumsi klasik tersebut uji $\mathrm{t}$ dan uji $\mathrm{F}$ yang dilakukan sebelumnya menjadi tidak valid dan secara statistik dapat mengacaukan kesimpulan.

\section{HASIL DAN PEMBAHASAN}

\section{Deskripsi Responden}

Deskripsi responden dikelompokkan kedalam lima kategori, yakni: usia, jenis kelamin, tanggungan keluarga, tingkat pendidikan, dan pengalaman beternal, sebagaimana terlihat pada gambar 1 berikut.

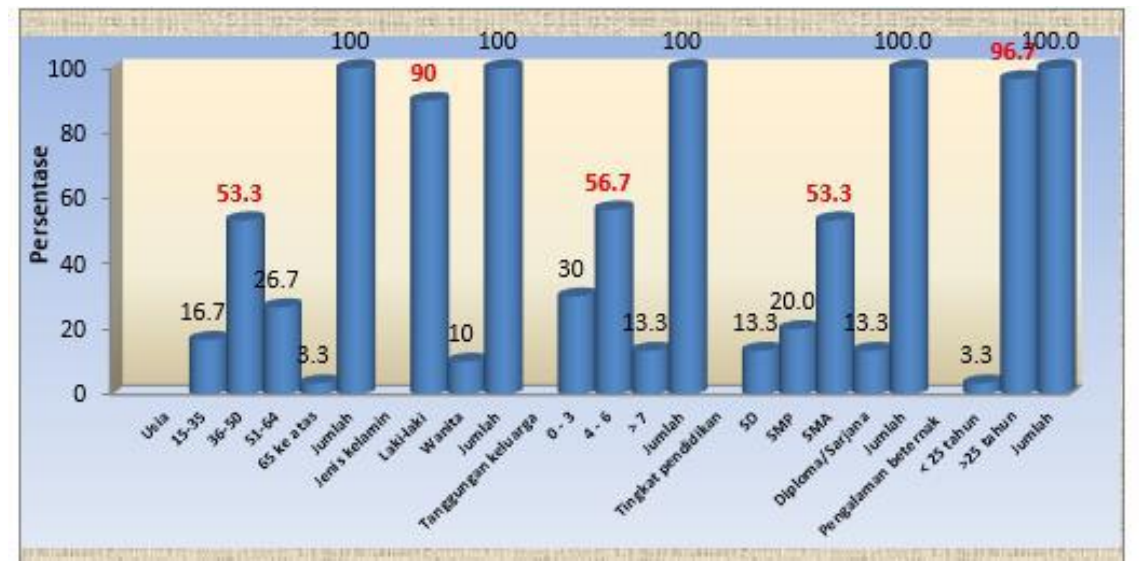

Gambar 1. Deskripsi Responden Peternak Ayam Petelur

Usia respoden umumnya usia menrupakan usia produktif menurut Biro pusat statistik usia antara 15-64 tahun 96,6\%, terdiri dari 53,3\% berada 36-50 tahun dan 51-64 tahun Pusat Satistik usia produktif itu adalah usia 15 sampai 64 tahun dan 3,6\% berusia tidak produktif yaitu satu orang responden berusia diatas 64 tahun.

Perlu diketahui umur peternak penting, karena struktur umur akan mempengaruhi kemampuannya dalam berusaha. Peternak yang lebih muda biasanya memiliki kemampuan fisik yang lebih kuat dan kesehatan yang lebih baik dibandingkan dengan peternak yang lebih tua (Sesriwita, 2005; Andri et al., 2011). Selain itu, cepat atau lambatnya peternak dalam melakukan adopsi inovasi juga dipengaruhi oleh umur (Soekartawi, 
1995). Sedangkan jenis kelamin $90 \%$ laki-laki, karena tanggungjawabnya yang telah dipilih sebagai petani ternak ayam petelur.

Jumlah tanggungan keluarga masing-masing responden, sebagian besar dari responden mempunyai anggota keluarga 4-6 orang yaitu sebesar 56,7 \%. Kebanyakan pengelolaan usaha ayam ras petelur dilakukan oleh tenaga kerja dalam keluarga, sesuai dengan pendapat Mubyarto (1985) yang mengemukakan bahwa dalam usaha tani sebagian besar tenaga kerja berasal dari anggota keluarga. Hal ini tercermin banyaknya anggota keluarga yang ikut terlibat dalam pengelolaan usaha peternakan ayam ras petelur.

Menurut Soekartawi (1995), pendidikan akan mempengaruhi petani dalam menentukan alternatif yang tepat dalam mengelola usahanya. Semakin tinggi tingkat pendidikan seseorang semakin cepat mereka menerima inovasi-inovasi baru (Mosher, 1981). Menurut Rasyaf (1995), untuk memecahkan masalah dan pengambilan keputusan di peternakan, kurang memiliki keterampilan. Disinilah letak perbedaannya, karena itulah diperlukan ilmu pengetahuan, dari gambar di atas dapat dilihat bahwa responden lebih banyak berpendidikan SMA yaitu sebanyak 16 orang atau 53,33\%, setelah itu berpendidikan SMP yaitu sebanyak 6 orang atau $20 \%$, kemudian berpendidikan Perguruan Tinggi dan berpendidikan SD sama banyak nya yaitu masing - masing sebanyak 4 orang atau $13,33 \%$.

Menurut Rasyaf (1995) keterampilan merupakan hal yang dapat dimiliki oleh setiap orang, dengan banyak berlatih dan pengalaman yang banyak, ia mampu mengelola usahanya dengan baik secara bertahap. Hasil penelitian menunjukkan bahwa pengalaman responden dalam beternak di atas 26 tahun, karena umumnya peternak sudah merintis usaha peternakan ayam ras petelur secara turun temurun. Dengan melihat pengalaman beternak masyarakat dapat diartikan bahwa kegiatan peternakan ayam ras ini sudah menjadi perekonomian daerah masyarakat dengan waktu yang cukup lama.

\section{Pendapatan Usaha ternak Ayam Ras Petelur}

Pendapatan adalah selisih antara penerimaan dengan biaya yang di keluarkan. Dari hasil penelitian diketahui bahwa komponen penerimaan dari suatu usaha ternak ayam ras petelur yang diusahakan adalah penjualan telur, ayam afkir dan penjualan tinja selama satu periode produksi. Satu periode produksi ayam ras petelur yaitu berkisar antara 18-24 bulan. Jumlah pemeliharaan ternak ayam ras petelur yang diusahakan peternak antara 3000 sampai 10.000 ekor pada usaha peternakannya.

Pengaruh yang sangat penting dalam mengetahui pendapatan yang diterima oleh peternak yaitu harga, baik harga jual produk maupun harga biaya produksi. Harga produk ini adalah penerimaan dari usaha yaitu berupa penjualan telur ayam, ayam afkir dan kotoran ayam sementara harga input produksi yang lebih umum disebut biaya juga perlu diperhitungkan yaitu biaya kandang, biaya bibit, biaya tenaga kerja, biaya pakan, biaya obat dan vaksin, dan biaya prasarana listrik. Pada kasus ayam petelur ini penekanan biaya produksi lebih bisa dikontrol oleh pengelola dari pada meningkatkan harga jual produksi karena pasar telur adalah persaingan sempurna.

Rata-rata jumlah ayam ras petelur yang diusahakan peternak di kecamatan Guguak dan Mungka per periode adalah \pm 6.844 ekor, rata-rata penerimaan peternak dari hasil penjualan telur adalah sebesar Rp 4.884.273.479,-, dari ayam afkir sebesar Rp. 149.297.000,- dan dari penjualan kotoran Rp 24.070.400,.Harga telur rata- rata perbutirnya pada saat penelitian antara Rp 980-1.150/ butir dan didapatkan rata-rata $\mathrm{Rp}$ 1.074/butir, harga penjualan ayam afkir berkisar antara Rp 20.000-30.000 /ekor. Ayam diafkir biasanya setelah berumur 24 bulan maksimal atau tergantung kondisi ayam pada saat akan afkir. Untuk hasil penjualan kotoran. Harga perkarungnya antara Rp 5.000 - 10.000 /karung. Ada juga pada penelitian ini kotoran ayam di jual borongan rata- rata dengan harga Rp 100.000,- untuk setiap kandangnya, tetapi lebih banyak hasil penjualan kotoran di ambil oleh tenaga kerja sebagai tambahan penghasilan. Namun pada penelitian ini di hitung penjualan kotoran per periode nya rata- rata sebesar Rp24.070.400,-

Penerimaan total dari usaha peternakan ayam ras ini di peroleh dari semua hasil penjualan telur, ayam afkir dan kotoran maka diperoleh penerimaan satu periode sebesar $\mathrm{Rp} 5.057 .640 .879,00$ / periode produksi. Penerimaan dan pengeluaran usaha ternak ayam ras petelur dalam penelitian ini dapat dilihat pada tabel 2 berikut.

Tabel 2. Rataan penerimaan dan pengeluaran usahaternak ayam ras petelur (periode produksi)

\begin{tabular}{lr}
\hline \multicolumn{1}{c}{ Uraian } & Rata-rata (Rp/periode produ \\
\hline Penerimaan & \\
$\cdot$ Penjualan telur & 4.884 .273 .479 \\
- Afkir & 149.297 .000 \\
$\cdot$ Kotoran Hewan & 24.070 .400
\end{tabular}




\begin{tabular}{lcc}
\hline \multicolumn{1}{c}{ Uraian } & Rata-rata (Rp/periode produksi) \\
\hline Total Penerimaan & & 5.057 .640 .879 \\
Pengeluaran & & \\
Biaya Tetap & & \\
· Penyusutan kandang & 31.953 .761 & \\
· Listrik dan prasarana & 5.408 .000 & \\
Biaya Variabel & & \\
· Pembelian Bibit & 379.533 .333 \\
· Pakan & 3.462 .390 .000 & \\
· Obat dan Vaksin & 10.879 .997 & \\
· Tenaga Kerja & 91.174 .667 & 3.981 .339 .758 \\
Total Pengeluaran & & 1.076 .301 .122 \\
Pendapatan & & \\
\hline
\end{tabular}

Sumber: Diolah dari data primer, 2017

Perhitungan total pengeluaran yaitu akumulasi sejumlah biaya yang dikeluarkan yang dalam produksi dengan rata-rata total pengeluaran per periode sebesar $\mathrm{Rp}$ 3.981.339.758,00. Pengeluaran dihitung berdasarkan harga faktor produksi yaitu biaya kandang yang dihitung sebagai biaya penyusutan dalam setiap periode produksi yaitu dua tahun pemakaian, pada umumnya ketahanan kandang yang dipakai rata-rata berumur 10-15 tahun, namun ada juga kandang yang disewa oleh peternak sebagai pengganti biaya kandang, pada penelitian ini di ambil pengeluran rata- rata biaya kandang per periode sebesar $\mathrm{Rp} 31.953 .761,-$. Biaya Listrik dan prasarana merupakan biaya yang dikeluarkan sesuai keadaan produksi, karena biaya ini dikeluarkan tetap dalam jangka pendek untuk periode produksi yang hanya digunakan seperlunyaseperti penerangan dan untuk prasarana mesin giling pakan serta operasional lain yang berkaitan dengan penggunaan listrik, dalam penelitian ini biaya yang harus dikeluarkan dalam satu periode produksi rata-rata sebesar Rp 5.408.000.

Penghitungan pengeluaran/biaya yang dikategorikan sebagai biaya variabel adalah biaya yang keadaannya berubah sesuai kondisi keadaan proses produksi, jika ingin meningkatkan proses produksi maka pengeluaran biaya variabel juga meningkat. Pada penelitian ini biaya variabel meliputi pembelian bibit, biaya pakan, biaya vaksin dan obat, serta tenaga kerja. Biaya bibit disini adalah biaya yang dikeluarkan untuk ayam yang sudah produktif bertelur dengan kisaran harga rata- rata $\mathrm{Rp} 50.000,00 \mathrm{Rp} 60.000,00$ rata- rata biaya yang dikeluarkan dalam penelitian ini untuk biaya bibit per periode sebesar Rp 379.533.333,00. Selanjutnya yang sangat menentukan dalam produksi ayam petelur adalah pakan, menurut Rasyaf (1995) pakan menempati 45-80\% dari total biaya produksi. Hal ini disebabkan oleh harga pakan yang tidak normal pada saat penelitian, harga pakan yang tinggi disaat penelitian menyebabkan biaya yang dikeluarkan oleh peternak juga tinggi. Rata - rata pengeluaran pakan yang sudah siap digunakan untuk konsumsi ternak ayam berkisar dari Rp 600,00 - Rp 800,00 per ekor untuk satu hari. Jika dalam satu periode produksi ayam petelur

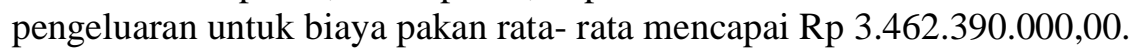

Biaya rata-rata yang di keluarkan untuk obat-obatan dan vaksin yaitu sekitar Rp10.879.997,00. Biaya ini sangat tergantung kepada keadaan fisiologis ayam dan lingkungan, jika kondisi ayam dalam keadaan normal biaya vaksin, obat dan vitamin bisa ditekan, ada kalanya biaya vaksin bisa meningkat apabila ayam dalam keadaan sakit dan lingkungan tidak mendukung untuk peternakan ayam petelur sehingga butuh perawatan khusus dari hama penyakit dan virus.

Penggunaan tenaga kerja yang dibayar lebih kepada semua kegiatan operasional kandang dengan upah yang dikeluarkan biasanya menggunakan satuan per ekor ayam per hari atau ada juga upah bulanan sesuai UMR, untuk upah sesuai UMR berkisar antara Rp 900.000,00 - Rp 1.500.000,00 per bulan, tetapi jika upah menggunakan satuan per ekor ayam rata- rata biaya yang dikeluarkan sebesar Rp 9,00 - Rp10,00 per ekor dalam satu hari kerja. Dari penelitian ini rata -rata upah tenaga kerja yang dikeluarkan peternak adalah sebesar Rp 91.174.667,00 dalam satu periode produksi.

Pendapatan adalah penerimaan yang diterima oleh peternak ayam dikurangi dengan biaya yang dikeluarkan dalam proses produksi untuk satu periode produksi yaitu dua tahun. Dalam penelitian ini rata rata pendapatan dalam satu periode produksi adalah sebesar Rp 1.076.301.122,00. maka dalam satu bulan rata-rata peternak ayam petelur memperoleh pendapatan sebesar $\mathrm{Rp} 44.845 .880,00$. Pendapatan ini di dapat setelah mengeluarkan seluruh biaya operasional yang diperlukan untuk pengelolaan usaha peternakan ayam ras petelur. 


\section{Hasil Pendugaan Model}

Sesuai dengan spesifikasi model pada metodologi penelitian, dimana variasi dari faktor yang mempengaruhi pendapatan ayam ras petelur adalah biaya penyusutan kandang, tenaga kerja, biaya bibit, biaya pakan, biaya obat, biaya listrik dan prasarana. Hasil regresi yang didapatkan dari pendugaan model ini adalah model terbebas dari kasus autokorelasi yang terlihat dari nilai D-Wnya 1.910, Menurut Firdaus, 2004 dalam Wati et al.. (2008), jika nilai D-W berada diantara 1,55 dan 2,46 berarti model yang digunakan terbebas dari kasus autokorelasi. Begitu juga dengan kasus heteroskedastisity dimana gambar scatterplot dari variabel yang mempengaruhi pendapatan tidak membentuk suatu pola tertentu atau menyebar. Model yang telah didapat dengan fungsi Cobb-Douglas akan meminimalkan terjadinya kasus multikoliniertas terjadi pada model ini. Hal ini dapat dideteksi dari nilai VIF yang lebih dari 1 dan angka tolerance yang mendekati 1 atau rata-rata diantara variabel memiliki nilai tolerance lebih kecil dari 1. Hasil pendugaan dari model sesuai terlihat pada tabel 3 berikut

Tabel 3. Hasil pendugaan model faktor produksi terhadap pendapatan usaha ternak ayam petelur

\begin{tabular}{|c|c|c|c|c|c|c|c|}
\hline \multirow[t]{2}{*}{ Model } & \multicolumn{2}{|c|}{$\begin{array}{l}\text { Unstandardized } \\
\text { Coefficients }\end{array}$} & \multirow{2}{*}{$\begin{array}{c}\text { Standardized } \\
\text { Coefficients } \\
\text { Beta }\end{array}$} & \multirow[t]{2}{*}{$\mathrm{t}$} & \multirow[t]{2}{*}{ Sig. } & \multicolumn{2}{|c|}{ Collinearity Statistics } \\
\hline & B & Std. Error & & & & Tolerance & VIF \\
\hline (Constant) & 2.547 & 4.490 & & .567 & .576 & & \\
\hline LnX1kan & -.010 & .195 & -.011 & -.053 & .958 & .263 & 3.800 \\
\hline LnX2tk & .570 & .217 & .483 & 2.635 & .015 & .336 & 2.976 \\
\hline $\operatorname{LnX} 3 b b$ & 1.744 & .633 & 1.047 & 2.755 & .011 & .078 & 12.785 \\
\hline LnX4pk & -.956 & .598 & -.587 & -1.598 & .124 & .084 & 11.949 \\
\hline LnX5ov & -.362 & .170 & -.308 & -2.127 & .044 & .540 & 1.852 \\
\hline LnX6pl & .022 & .174 & .020 & .123 & .903 & .417 & 2.397 \\
\hline
\end{tabular}

a. Dependent Variable: Pendapatan

Berdasarkan hasil pendugaan model diatas, nilai konstanta (B) sebesar 2,547 lebih besar dari nilai 1 (satu) hal ini dapat menggambarkan bahwa keadaan usaha peternakan ayam petelur di lokasi penelitian berada pada keadaan increasing return to scale yang berarti skala usaha masih bisa dikembangkan dengan mengoptimalkan penambahan input agar hasil yang di dapatkan lebih maksimal. Dilihat dari variabel yang paling mempengaruhi pendapatan peternakan adalah biaya bibit ayam petelur dengan nilai koefisien regresi adalah 1,744 yang bernilai positif hal ini berarti bahwa dengan menekan biaya bibit ayam petelur sebesar satu rupiah maka akan menaikkan pendapatan sebesar 1,744 rupiah, begitu juga dengan hasil pendugaan model dari variabel tenaga kerja dan biaya prasarana dimana penekanan upah tenaga kerja 1,00 rupiah akan menaikan pendapatan peternak ayam sebesar 0,57 rupiah, begitu juga untuk biaya listrik dan prasarana tetapi berbeda dengan variabel lainnya dimana ada variabel yang berpengaruh negatif seperti biaya kandang, pakan dan obat-obatan vaksin, dimana jika penambahan biaya dari variabel itu dilakukan akan meningkatkan pendapatan peternak ayam sebesar nilai satuan yang berada pada hasil pendugaan model.

Tabel 4. Hasil Pendugaan model regresi

\begin{tabular}{|c|c|c|c|c|c|c|c|c|c|c|}
\hline \multirow[b]{2}{*}{ Model } & \multirow[b]{2}{*}{$\mathrm{R}$} & \multirow[b]{2}{*}{ R Square } & \multirow[b]{2}{*}{$\begin{array}{l}\text { Adjusted R } \\
\text { Square }\end{array}$} & \multirow[b]{2}{*}{$\begin{array}{l}\text { Std. Error of the } \\
\text { Estimate }\end{array}$} & \multicolumn{5}{|c|}{ Change Statistics } & \multirow[b]{2}{*}{$\begin{array}{l}\text { Durbin- } \\
\text { Watson }\end{array}$} \\
\hline & & & & & $\begin{array}{l}\text { R Square } \\
\text { Change }\end{array}$ & F Change & df 1 & df 2 & $\begin{array}{l}\text { Sig. F } \\
\text { Change }\end{array}$ & \\
\hline 1 & $.860^{\mathrm{a}}$ & .740 & .672 & .32692 & .740 & 10.919 & 6 & 23 & .000 & 1.910 \\
\hline
\end{tabular}

Hasil uji regresi dari model ini adalah signifikan, hal ini dilihat secara bersama-sama variabel yang mempengaruhi pendapatan berpengaruh secara signifikan dengan nilai $\mathrm{F}$ hitung sebesar10,919 lebih kecil dari $\mathrm{F}$ tabel, berartisecara keseluruhan variabel bebas seperti biaya kandang, tenaga kerja, bibit, pakan, obat, dan biaya listrik bisa men-jelaskan secara signifikanpengaruhnya terhadap pendapatan di dalam model. Hal ini juga ditunjukkan oleh nilai Adjusted R2/ R Square nya yang tinggi $(0,672)$ dannilai R2/R Square nya adalah 0,740 , yang erarti bahwa variabel penjelas yang dimasukkan dalam model ini $74 \%$ bias menjelaskan faktorfaktor yang mempengaruhi pendapatan sedangkan sisa dijelaskan oleh variabel lain diluar model. 


\section{KESIMPULAN}

Berdasarkan hasil penelitian yang dilakukan pada usaha ternak ayam ras petelur di kecamatan Guguak dan Mungka dapat disimpulkan sebagai berikut:

1. Karakteristik demografi dan sosial ekonomi peternak memberikan pengaruh secara tidak langsung terhadap besarnya pendapatan yang di terima peternak dari usaha ternak ayam ras petelur. Pendapatan rata-rata perbulannya adalah Rp.44.845.880,00;

2. Faktor-faktor produksi yang berpengaruh terhadap pendapatan usaha ternak ayam petelur adalah biaya bibit dan biaya tenaga kerja berpengaruh positif dan signifikan, sedangkan biaya obat-obat dan vaksin berpengaruh negatif dan signifikan. Namun biaya kandang bepengaruh negatif dan non signifikan mempengaruhi pendapatan. Dengan kelayakan model mem-perlihatkan $74 \%$ variable penjelas dalam model bisa menjelaskan faktor yang mempengaruhi pendapatan;

3. Faktor-faktor produksi yang diduga berpengaruh positif dan signifikan secara simultan terhadap pendapatan usaha ternak ayam petelur adalah bibit dan tenaga kerja, sedangkan posisi produksi yang digambarkan dari nilai $\beta$ (konstanta) 2,547 yang lebih besar dari satu menyatakan keadaan usaha peternakan ayam petelur masih dalam keadaan increasing return to scale.

Berdasarkan penelitian di atas dapat diberikan beberapa saran rekomendasi sebagai berikut:

1. Kabupaten Lima puluh kota merupakan sentra produksi ayam petelur di Sumatera Barat, belum mengalami kesulitan dalam pemasarannya, karena berada pada posisi strategis sebagai penghubung kota Bukittinggi dan Pekanbaru. Namun peningkatan produksi masih bisa dioptimalkan karena dalam keadaan Increasing return to scale.

2. Mengingat pengalaman beternak di atas 25 tahun, memungkinkan daerah ini dijadikan pilot project percontohan untuk pengembangan usaha ternak ayam petelur di daerah lain, sehingga bisa menjadi Lingkungan agroindustri peternakan yang pengelolaannya mulai dari hulu sampai hilir berjalan secara efisien. Efisiensi menjadi faktor kunci agar dapat menghasilkan harga pokok produksi yang mampu bersaing, sehingga pada giliriannya memiliki keunggulan komparatif (comparative advantage) dan sekaligus keunggulan kompetitif (competitive advantage) yang akhirnya bisa menjaga stabilitas harga telur ayam, dimana beberapa bulan yang lalu menjadi penyebab inflasi di tingkat nasional. Dari sisi ini pemerintah harus membina dan memproteksi usaha ternak ayam petelur ini supaya berkelanjutan (sustainable).

\section{UCAPAN TERIMA KASIH}

Terima kasih disampaikan kepada bapak Nofialdi dan ibu Dwi Yuzaria yang menyediakan waktunya untuk diskusi dan presentasi tim peneliti pada pascasarjana Magister Ilmu Ekonomi Pertanian Fakultas Pertanian Universitas Andalas dan para peternak ayam petelur yang digunakan waktunya untuk wawancara dalam pelaksanaan penelitian ini.

\section{DAFTAR PUSTAKA}

Andri, R. Wati, dan A. Suresti. 2011. Analisis Faktor-Faktor yang Mempengaruhi Pendapatan Peternak Ayam Ras Petelur di Kecamatan Lareh Sago Halaban Kabupaten Lima Puluh Kota. Jurnal Peternakan Indonesia 13(3): $205-$ 214.

BPS Lima Puluh Kota. 2015. Lima Puluh Kota Dalam Angka. Padang: Dinas Peternakan Provinsi Sumatera Barat.

Mosher, A. 1981. Menggerakkan dan Membangun Pertanian, Syarat-Syarat Pokok Pertanian dan Modernisasi. CV Yasaguna. Jakarta.

Mubyarto. 1985. Pengantar Ekonomi Pertanian. Jakarta: Lembaga Penelitian, Pendidikan dan Penerangan Ekonomi dan Sosial.

Rasyaf, M. 1995. Pengelolaan Produksi Telur. Yogyakarta: Kanisius.

Soekartawi. 1995. Ilmu usaha Tani. Jakarta: Universitas Indonesia. 